\title{
Dysmenorrhea among students in Yaounde, Cameroon: associated factors and socio-cultural aspects
}

\section{Jeanne Hortence Fouedjio, ${ }^{1,2}$, Florent Ymele Fouelifack ${ }^{1,3,4}$, Jovanny Tsuala Fouogue, Lionel Etame $^{3}$, Loic Dongmo Fouelifa ${ }^{6}$, Robinson Enow Mbu ${ }^{1,2}$}

\author{
${ }^{1}$ Department of Gynaecology and Obstetrics, Yaounde Central Hospital, Yaounde-Cameroon \\ ${ }^{2}$ Department of Gynaecology and Obstetrics, University of Yaounde, Yaounde-Cameroon \\ ${ }^{3}$ Department of Gynecology and Obstetrics, Higher Institute of Medical Technology, Nkolondom, Yaounde-Cameroon \\ ${ }^{4}$ Associative Group for Research, Education and Health, Station-Falaise, Dschang Cameroon \\ ${ }^{5}$ Gynaeco-Obstetric Unit, Bafoussam Regional Hospital, Bafoussam, Cameroon \\ ${ }^{6}$ School of Health Services of the Armies of Lome, Lome-Togo
}

Received: 09 June 2019

Accepted: 03 July 2019

\section{*Correspondence:}

Dr. Fouedjio Jeanne Hortence,

E-mail: fouedjiojeanne@yahoo.fr

Copyright: (C) the author(s), publisher and licensee Medip Academy. This is an open-access article distributed under the terms of the Creative Commons Attribution Non-Commercial License, which permits unrestricted non-commercial use, distribution, and reproduction in any medium, provided the original work is properly cited.

\begin{abstract}
Background: Dysmenorrhea is very common disorder. It affects the quality of life and is the main cause of school absenteeism's among teenagers. The goal of this study was to determine socio-cultural aspects of dysmenorrhea among students in Yaounde and factors associated with it.

Methods: Authors carried out a cross sectional analytic study in 2 secondary schools and a higher institute in Yaounde, from December 1, 2017 to June 30, 2018 (7 months). Authors included all students aged at least 15, in form 5 and above. In the higher institute, sampling was consecutive, while it was stratified into 2 clusters in the secondary schools. Odds ratios were determined to assess association between variables and $\mathrm{P}$-value $<0.05$ was considered significant.

Results: Of the 1059 participants, 800 had dysmenorrhea (prevalence: $75.5 \%)$. Mean age was $18.88 \pm 3.62$ years (range: 15-45 years). Family history of dysmenorrhea (OR: 4.20 (95\% CI: 3.02-5.83)) and stress ((OR: 2.16 (95\% CI: 1.55 - 3.02)) were significantly associated with dysmenorrhea. A duration of menses $\leq 3$ days was protective ((OR: 0.31 (95\% CI: 0.12-0.82)). Dysmenorrhea remains a taboo for $23.6 \%$ of participants.

Conclusions: Family history of dysmenorrhea and stress are risk factors for dysmenorrhea which remains a taboo for almost a fourth of affected women. Authors recommend educating women about dysmenorrhea and control psychosocial stress.
\end{abstract}

Keywords: Cameroon, Cultural, Dysmenorrhea, Epidemiology, Risk factors, Social, Students

\section{INTRODUCTION}

Dysmenorrhea is the most common gynecological complain among women of childbearing age. ${ }^{1-3}$ For more than $50 \%$ of women of childbearing age (much more among adolescents), it is the leading cause of school and professional absenteeism, this represents 600 million of lost hours per year and costs approximately 2 billion dollars in the United States of America. ${ }^{1,4,5}$ Globally, the prevalence of dysmenorrhea reported in the literature varies from $16 \%$ among Japanese women aged 17 to 51 years to $93 \%$ among Australian teenagers (15-19 years) in $2010 .^{6,7}$ In Canada the prevalence was $60 \%$ in 2005 and the following factors were associated: young age, 
smoking and non-use of oral contraceptives. ${ }^{8}$ In 2012 in Brazil, the prevalence of dysmenorrhea was up to $86 \%$ in a high school. ${ }^{9}$ A study in Croatia found a prevalence of dysmenorrhea of $55 \%$ among in primary and secondary schoolgirls, with a rate of absenteeism of $22 \%$ among affected girls. ${ }^{3}$ In 2014, a study in South-Korea reported that stress, duration of menstruation and eating habits were associated with dysmenorrheal. ${ }^{10}$

In Africa, a study in Egypt in 2012, reported a prevalence of $76.1 \%$ and stated that dysmenorrhea was associated with early menarche and irregular and long menstrual cycles. ${ }^{11}$ The following prevalence's were reported in Sub-Saharan Africa: $74.4 \%$ in Ghana, $77.3 \%$ in Rwanda, $43.3 \%$ in Nigeria. ${ }^{12-14}$ To the best of our knowledge no study has been published on dysmenorrhea in Cameroon. The goal of this study was to determine the factors associated with dysmenorrhea and its sociocultural aspects students in Yaounde (Cameroon).

\section{METHODS}

This cross-sectional and analytic study was conducted from December 1, 2017 to June 30, 2018 (7 months) in 2 secondary schools (College la Retraite and Biyem-Assi Government High School) and 1 University (Catholic Institute of Yaounde) in Yaounde, the political capital of Cameroon.

The target population was made up of 324 participants. In the two secondary schools, sampling was stratified into 2 clusters; At first, in each school 6 enumerations areas were set for from 5 and from 6 classes, 5 enumeration zones were set for from 7 classes. Secondly data were collected from eligible students present the day of the survey. Sampling in the University was consecutive. Both samples were exhaustive. The minimum sample size was determined by the Lorenz formula: $\mathrm{N}=\mathrm{Z}^{2} \times \mathrm{P}(1-\mathrm{P}) / \mathrm{d}^{2}$. $((\mathrm{N}=$ minimum sample size; $\mathrm{Z}=$ Confidence level $(\mathrm{Z}=1.96$ for a confidence level of $95 \%$ ), $\mathrm{P}=69.8 \%$ (prevalence of dysmenorrhea in a study conducted in Nigeria at the University of Maiduguri in 2010), and $\mathrm{d}=5 \%$ (margin of error tolerated)) 324 participants. $^{25}$

A clearance (Number: 1486 CEI-UDo/06/2018/T) was issued by the Institutional Ethical Committee of the University of Douala. We also got authorizations from executives of the schools and the Ministry of Education. We carried out the study in accordance with the Helsinki declaration on research involving human subjects. Questionnaires were anonymous and data were used only for research purposes.

\section{Inclusion criteria}

- Students above 15 years already having menses.

\section{Exclusion criteria}

- Participants who withdrew their consents
- Participants with unusable questionnaires.

\section{Statistical analysis}

Students above 15 years were invited to give their informed consent. Data were collected during a face-toface interview using a pretested anonymous questionnaire. Data were computerized with CSpro 7.0 software and analyzed with Microsoft Excel 2013 and SPSS version 20 . Odds ratio (OR) with a $95 \%$ confidence was used to assess associations between variables. p-value below 0.05 was considered significant.

\section{RESULTS}

Table 1: Socio-demographic and obstetric characteristics.

\begin{tabular}{|lll|}
\hline Characteristics & N & $\%$ \\
\hline Age & & \\
\hline $15-19$ & 424 & 53.0 \\
\hline $20-24$ & 226 & 28.3 \\
\hline $25-29$ & 83 & 10.3 \\
\hline$\geq 30$ & 67 & 8.4 \\
\hline Education level & & \\
\hline Secondary school & 635 & 79.4 \\
\hline University & 165 & 26.6 \\
\hline Marital status & & \\
\hline Single & 587 & 73.4 \\
\hline Married & 213 & 26.6 \\
\hline Gravida & & \\
\hline 0 & 728 & 91.0 \\
\hline 1 & 52 & 6.5 \\
\hline$\geq 2$ & 20 & 2.5 \\
\hline Para & & \\
\hline 0 & 740 & 92.5 \\
\hline 1 & 49 & 1.4 \\
\hline$\geq 2$ & 11 & \\
\hline & & 6.1 \\
\hline
\end{tabular}

Table 2: Factors associated with dysmenorrhea.

\begin{tabular}{|l|l|}
\hline Factors & $\begin{array}{l}\text { Adjusted Odds } \\
\text { Ratios (95\% CI) }\end{array}$ \\
\hline Age $\leq 19$ years & $3.23(0.79-4.03)$ \\
\hline $\begin{array}{l}\text { Early menarche } \\
\text { (before 12 years old) }\end{array}$ & $1.8(0.94-3.12)$ \\
\hline $\begin{array}{l}\text { Abundance of menstrual flow } \\
\text { (with clots) }\end{array}$ & $2.7(0.84-4.65)$ \\
\hline $\begin{array}{l}\text { Long menstrual period } \\
\text { (more than 7 days) }\end{array}$ & $3.04(0.59-4.89)$ \\
\hline Regularity of menstrual flow & $1.52(0.76-3.01)$ \\
\hline Sexual activity & $3.02(0.84-5.13)$ \\
\hline Family history of dysmenorrhea & $4.20(3.02-5.83)$ \\
\hline Psychosocial stress & $2.16(1.55-3.2)$ \\
\hline Early menarche (before 12 years) & $0.31(0.12-0.82)$ \\
\hline
\end{tabular}


The prevalence of dysmenorrhea was $75.5 \% \quad(800$ participants out of 1059). Mean age of participants was $18.88 \pm 3.62$ years ranging from 15 to 45 years. Most participants were between 15 and 19 years and a great majority were singles (Table 1). Most of them had never been pregnant $(92.5 \%)$.

Factors associated with dysmenorrhea (Table 2). Family history of dysmenorrhea $(\mathrm{aOR}=4.20 ; 95 \% \mathrm{CI}: 3.02-5.83$, $\mathrm{p}$ value $=0.00)$ and psycho social stress (aOR: 2.16; $95 \%$ CI: $1.55-3.2$; p value $=0.00$ ), were risks factors of dysmenorrhea while short menses (less than days) was protective (aOR: 0.31, 95\%CI: 0.12-0.82, $\mathrm{p}$ value $=0.02$ ).

\section{DISCUSSION}

\section{Prevalence of dysmenorrhea}

Authors found a prevalence of $75.5 \%$ among pupils and students. This prevalence is close to figures reported in Africa and in Turkey: 75\% in Mansoura-Egypt, $76.1 \%$ in Assiut-Egypt, $74.3 \%$ in Ghana, $77.3 \%$ in Rwanda and $72.7 \%$ in Turkey. ${ }^{11-16}$ Some studies have reported higher prevalences: $85.1 \%$ in Ethiopia, $80.5 \%$ in Rouen-France, $91.2 \%$ in Marrakech-Morocco and $86.6 \%$ in Switzerland. ${ }^{1,8,17,18}$

Lower prevalence's have also been reported: $53.3 \%$ in Nigeria and $55.5 \%$ in Turkey. ${ }^{14,} 19$ This broad variability in prevalence may be due to the different methods of data collection, the different definitions of dysmenorrhea, the various populations studied and the context in which the studies were conducted. ${ }^{20,21}$

\section{Factors associated with dysmenorrhea}

Age and early menarche (before 12 years)

In this study, age $\leq 19$ was not was not associated with dysmenorrhea as previously reported by Jamieson et al. ${ }^{22}$ Early menarche (before 12 years) was not associated with Socio-demographic and obstetric features

Average age was $18.88 \pm 3.62$ years, with extremes ranging from 15 to 45 years. The 15 to 19 age group was the most represented with a frequency of 53\%. Similar findings were reported by Habibi et al, who found that $86.6 \%$ of women suffering from dysmenorrhea were between 16 and 20 years old. ${ }^{21}$

A great majority of participants $(96.5 \%)$ were single: that was predictible given the high proportion of teenagers. Most participants suffering from dysmenorrhea had never been pregnant. This is explained by the high proportion of teenagers and by the fact that primary dysmenorrhea usually disappears after the first delivery. dysmenorrhea in our series; this is in line with results found among French and Nigerian women. ${ }^{14,18}$ On the contrary, Harlow et al reported than early age at menarche increase the occurrence of dysmenorrheal. ${ }^{23}$

\section{Abundance of menses (with clots inside)}

Unlike other researchers we found that abundance of the menstrual flow did not significantly increase the occurrence of dysmenorrheal. ${ }^{16,24}$

\section{Long menses (more than 7 days)}

In our study, there was no association between long menses (more than 7 days) and dysmenorrhea. These results are similar to those published by Blondel et al, and Adham et al, in France and United States of America respectively but differ from those reported by El-Gilany et al, in Egyptians women. ${ }^{15,18,25}$ This may be due racial differences.

\section{Regularity of the menstrual cycle}

There was no significant relationship between the regularity of the menstrual cycle and the occurrence of dysmenorrhea. Again, there is discrepancy between previously published studies. ${ }^{15,25}$

\section{Sexual activity}

There was no association between sexual activity and dysmenorrhea. The discrepancy observed in literature on that issue may be explained by the prevalence of sexually transmitted infections which are known to increase the occurrence and severity of dysmenorrheal., ${ }^{3,26}$

\section{Family history of dysmenorrhea}

Like several authors from different continents, authors found a strong association between family history and dysmenorrhea in accordance with its genetic etiology. ${ }^{19,21,27,28}$

\section{Psycho-social stress}

Authors found that psycho-social stress was associated with dysmenorrhea; this is in accordance with results of several others studies. ${ }^{10,29,30}$ To the best of our knowledge the mechanism is still to be determined.

\section{Short menses}

Authors found that a short menses ( $\leq 3$ days) was protective against dysmenorrhea. Several authors reported similar findings. ${ }^{10,14,16,23,31}$

\section{CONCLUSION}

The prevalence of dysmenorrhea is very high among teenagers in Yaounde-Cameroon. Family history of dysmenorrhea and stress are risk factors of dysmenorrhea. Some affected women choose to keep it secret while others need emotional support from their relatives. Authors recommend educating women about dysmenorrhea and assist them in dealing with stress. 


\section{ACKNOWLEDGMENTS}

Authors are grateful to all participants and to executives of the three schools where the study was conducted.

Funding: No funding sources

Conflict of interest: None declared

Ethical approval: Ethical clearance: 1486 CEIUDo/06/2018/T issued by the Institutional Ethical Committee of the University of Douala-Cameroon.

\section{REFERENCES}

1. Narring F, Yaron M, Ambresin AE. Dysmenorrhea: a problem for the pediatrician?. Arch Pediatrics. 2012;19(2):125-30.

2. Graz B, Savoy M, Buclin T, Bonvin E. Dysmenorrhea: patience. Rev Med Switzerland. 2014;10:2285-8.

3. Strinić T, Buković D, Pavelić L, Fajdić J, Herman I, Stipić I, et al. Anthropological and clinical characteristics in adolescent women with dysmenorrhea. Coll Antropol. 2003;27(2):707-11.

4. Brühwiler H, Sieger D, Lüscher KP. Dysménorrhée primitive. In: Forum Médical Suisse. 2006;6(41):919-22.

5. Bahmani M, Eftekhari Z, Jelodari M, Saki K, Abdollahi R, Majlesi M, et al. Effect of Iranian herbal medicines in dysmenorrhea phytotherapy. J Chem Pharm Res. 2015;2:519-26.

6. Ohde S, Tokuda Y, Takahashi O, Yanai H, Hinohara S, Fukui T. Dysmenorrhea among Japanese women. Int J Gynecol Obstet. 2008;100(1):13-7.

7. Parker MA, Sneddon AE, Arbon P. The menstrual disorder of teenagers (MDOT) study: determining typical menstrual patterns and menstrual disturbance in a large population-based study of Australian teenagers. BJOG. 2010;117(2):185-92.

8. Burnett MA, Antao V, Black A, Feldman K, Grenville A, Lea R, et al. Prevalence of primary dysmenorrhea in Canada. J Obstet Gynaecol Can. 2005;27(8):765-70.

9. Brito SA, Marques CCC, Alves DS, Da Silva AC. Prevalence of dysmenorrhea in undergraduate health courses at an institution of higher education. Rev Enferm UFPE Line. 2012;6(6):1386-94.

10. Jeon GE, Cha NH, Sok SR. Factors influencing the dysmenorrhea among Korean adolescents in middle school. J Phys Ther Sci. 2014;26(9):1337-43.

11. Mohamed EM. Epidemiology of dysmenorrhea among adolescent students in Assiut City, Egypt. Life Sci J. 2012;9(1):348-53.

12. Gumanga SK, Kwame-Aryee RA. Menstrual characteristics in some adolescent girls in Accra, Ghana. Ghana Med J. 2012;46(1).

13. Kakoma JB, Gasana GK, Nkurunzinza J, Ngirinshuti JP. Dysmenorrhea and other menstrual characteristics in Rwandan female students at National University of Rwanda and Nyanza schoolgirls (Huye And Nyanza Districts/Southern
Province of Rwanda). Rwanda Med J. 2010;68(3):25-31.

14. Loto OM, Adewumi TA, Adewuya AO. Prevalence and correlates of dysmenorrhea among Nigerian college women. Aust N Z J Obstet Gynaecol. 2008;48(4):442-4.

15. Gilany AH, Badawi K, El Fedawy S. Epidemiology of dysmenorrhoea among adolescent students in Mansoura, Egypt. East Mediterr Heal J. 2005;11(12):155-63.

16. Unsal A, Ayranci U, Tozun M, Arslan G, Calik E. Prevalence of dysmenorrhea and its effect on quality of life among a group of female university students. Ups J Med Sci. 2010;115(2):138-45.

17. Shiferaw MT, Wubshet M, Tegabu D. Menstrual problems and associated factors among students of Bahir Dar University, Amhara National Regional State, Ethiopia: a cross-sectional survey. Pan Afr Med J. 2014;17.

18. Baker FC, Driver HS, Rogers GG, Paiker J, Mitchell D. High nocturnal body temperatures and disturbed sleep in women with primary dysmenorrhea. Am J Physiol-Endocrinol Metab. 1999;277(6):E1013E1021.

19. Ozerdogan N, Sayiner D, Ayranci U, Unsal A, Giray S. Prevalence and predictors of dysmenorrhea among students at a university in Turkey. Int J Gynecol Obstet. 2009;107(1):39-43.

20. Charandabi SMA, Nashtaei MS, Kamali S, Majlesi $\mathrm{R}$. The effect of acupressure at the Sanyinjiao point (SP6) on primary dysmenorrhea in students resident in dormitories of Tabriz. Iran J Nurs Midwifery Res. 2011;16(4):309.

21. Habibi N, Huang MSL, Gan WY, Zulida R, Safavi SM. Prevalence of primary dysmenorrhea and factors associated with its intensity among undergraduate students: a cross-sectional study. Pain Man Nurs. 2015;16(6):855-61.

22. Jamieson DJ, Steege JF. The prevalence of dysmenorrhea, dyspareunia, pelvic pain, and irritable bowel syndrome in primary care practices. Obstet Gynecol. 1996;87(1):55-8.

23. Harlow SD, Park M. A longitudinal study of risk factors for the occurrence, duration and severity of menstrual cramps in a cohort of college women. BJOG. 1996;103(11):1134-42.

24. Patel V, Tanksale V, Sahasrabhojanee M, Gupte S, Nevrekar P. The burden and determinants of dysmenorrhoea: a population-based survey of 2262 women in Goa, India. BJOG. 2006;113(4):453-63.

25. Baker FC, Driver HS, Rogers GG, Paiker J, Mitchell D. High nocturnal body temperatures and disturbed sleep in women with primary dysmenorrhea. Am J Physiol-Endocrinol Metab. 1999;277(6):E1013E1021.

26. Sun Y, Wang L, Li G. Investigation on influencing factors of primary dysmenorrhea in 1800 female college students (J). Tianjin $\mathbf{J}$ Tradit Chin Med. 2009;5:011 
27. Ju H, Jones M, Mishra G. The prevalence and risk factors of dysmenorrhea. Epidemiol Rev. 2013;36(1):104-13.

28. Parveen N, Majeed R, Rajar UD. Familial predisposition of dysmenorrhea among the medical students. Pak J Med Sci. 2009;25(5):857-60.

29. Wang L, Wang X, Wang W, Chen C, Ronnennberg AG, Guang W, et al. Stress and dysmenorrhoea: a population based prospective study. Occup Env Med. 2004;61(12):1021-6.

30. László KD, Gy\Horffy Z, Ádám S, Csoboth C, Kopp MS. Work-related stress factors and menstrual pain: a nation-wide representative survey. J Psychosom Obstet Gynecol. 2008;29(2):133-8.
31. Wildemeersch D. A frameless LNG-IUD may be preferred over framed LNG-IUD for the treatment of primary dysmenorrhea. Hum Reprod Update. 2016;22(3):404-7.

Cite this article as: Fouedjio JH, Fouelifack FY, Fouogue JT, Etame L, Fouelifa LD, Mbu RE.

Dysmenorrhea among students in Yaounde, Cameroon: associated factors and socio-cultural aspects. Int J Reprod Contracept Obstet Gynecol 2019;8:3339-43. 